\title{
SOIL PROPERTIES INFLUENCING PHYTOPARASITIC NEMATODE POPULATION ON CHILEAN VINEYARDS
}

\author{
Mario Fajardo P. ${ }^{1 *}$, Erwin Aballay E. ${ }^{1}$, and Manuel Casanova P. ${ }^{1}$
}

\begin{abstract}
Lifecycle of phytoparasitic nematode takes place in the rhizosphere, therefore their breeding, parasitism and mobility dynamics are inevitably influenced by the soil-root interaction, A study was performed to evaluate the influence of Vitis rootstocks to some plant parasitic nematodes under different soil conditions. Nematode populations were assessed in Vitis vinifera L. var. Chardonnay plants grafted on two rootstocks (K5BB, SO4) and ungrafted 'Chardonnay' as a control in three diferent alluvial soils in the central zone of Chile. Soils were two Inceptisols of the Casablanca Valley (Valparaíso Region), the first one without soil structure and with a densification zone in depth (S1) and the second one with sandy textural class (S3). A third soil was a Mollisol (S2) more structured than the others, situated on a locality of Melipilla (Metropolitan Region). The soils were characterized physically and morphologically and nematode genera were identified and counted using a dissecting microscope. 'Chardonnay' presented the highest population of Meloidogyne spp. on the three soil conditions but only significant in S2 soil. The population of Xiphinema spp. and Mesocriconema xenoplax were not representative enough to relate them with either soil or the different rootstocks. The amount of Meloidogyne spp. was inversely related with the sand content but positively related with the more structured soil. The stepwise regressions resulted useful when relating nematode populations with multiple soil factors.
\end{abstract}

Key words: Nematodes, rootstocks, K5BB, SO4, Chardonnay, rizosphere soil.

$\mathrm{T}$ he presence of plant-parasitic nematodes in vineyards is associated with a lower production and in some cases to a total loss; in fact, Smiley (2005) estimate that plant-parasitic nematodes cause worldwide losses of US\$78 billion in a year. Traditional control methods are based in the use of expensive and soil polluting chemicals. Until now, the biggest infestations on soils are treated with pre plantation fumigants, like methil bromide or 1,3D (Aballay and Montedónico, 2001). Some integrated managements includes the use of amendments and plant parasitic resistant rootstocks (Bell et al., 2000).

Despite their parasitic behavior, plant-parasitic nematodes spend a considerable part of their life-cycle in the soil. In addition to the host plant, soil type is also known to be a major factor that affects nematodes distribution. For example, Meloidogyne spp. occurs more frequently and more abundantly in sandy soils

${ }^{1}$ Universidad de Chile, Facultad de Ciencias Agronómicas, Casilla 1004, Santiago, Chile.

*Corresponding author (mariofajardop@gmail.com).

Received: 22 January 2010.

Accepted: 27 May 2010. than in clay soils (Prot and Van Gundy, 1981; Dabiré and Mateille, 2004). As invertebrate organisms that move through the soil porous space, the nematodes movement and the damage that they produce are determined greatly by soil physical and morphological properties (Neher $e t$ al., 1999). In that sense Esquivel (1996) observed that combination of an adequate porous space (of particles size and inter-particles space) and water content are keys on the proliferation of nematode communities, since water films would allow their movement and therefore the access to food. It is well documented that well drained soils and macroporosity have an influence on the higher population of plant parasitic nematodes (Bouwman and Arts, 2001; Avendaño et al., 2004; Aballay, 2007).

It has been observed that Meloidogyne spp. are directly influenced by the sand percentage. Arévalo et al. (2007) observed that in soils with more than $50 \%$ of sand, Meloidogyne spp. presented more mobility and infectivity on traditional cocoa plantations. This soil texture incidence is determined by a higher macroporosity, which produces more air circulation and a consequent acceleration of the biological processes. On the other hand the soil structure, 
water content, and thus porous space have an influence in the nematodes population also, Neher et al. (1999) argue that the inter-aggregate space offers a better environment than the intra-aggregate space for nematodes populations, and then a correct morphological description becomes essential for any nematodes study. Well-structured soils permits better transport porosity, which increases the plant-parasitic nematodes movements and infectivity (García del Pino, 1994).

Rootstocks in Chile are used under different soils and climatic conditions, for this reason it is interesting to assess the soil properties effects on the rootstocks plantparasitic nematodes control. Although there are some attempts of measuring the effect of soil conditions on nematodes population and infectivity (Neher et al., 1999; Cadet et al., 2004; Avendaño et al., 2004), none has been carried out on Chilean conditions.

Therefore, the aim of this study was to evaluate the relations of soil properties and some vine (Vitis vinifera L.) rootstocks on nematode populations measured in the Central Zone of Chile.

\section{MATERIALS AND METHODS}

The present study was carried out on three vineyards established under different soil and geomorphologic characteristics. The incidence of two rootstocks and an ungrafted variety of $V$. vinifera plantations of more than 6-yr old were evaluated on the presence of plantparasitic nematodes. The initial nematodes analyses were similar for the three rootstocks on each soil, since their soil management was uniform previous establishment. The determination of soil characteristics and nematode presence was carried out since December 2006 through February 2007.

The selected rootstocks were 'K5BB' and 'SO4', which are commonly used on the zone, both hybrids of $V$. berlandieri $\times V$. riparia. As control variety was used 'Chardonnay' because its high susceptibility to plantparasitic nematodes (Aballay and Montedónico, 2001).

The Table 1 presents a synthesis of the three studied soils in terms of its location, taxonomic classification, and geomorphic position (CNR, 1981; CIREN, 1996).

A morphological description was performed to every soil-rootstock combination (nine in total), according to the standard procedure described by Schoeneberger et al. (2002). Five plants for each rootstock were randomly selected on each vineyard site and six soil samples of 250 $\mathrm{cm}^{3}$ were taken from two depths $(0-30 \mathrm{~cm}$ and $30-60 \mathrm{~cm})$ with an auger of $7 \mathrm{~cm}$ diameter resulting 12 soil and roots (six per depth) samples per plant on a regular sampling patron (Figure 1).

The roots $\leq 2 \mathrm{~mm}$ were separated on sealed bags from each sample (12 samples per plant). The physicals analysis (texture, particle density, and water retention) and both identification and recognition of nematode population were analyzed from a mixed sample for the two depths (two samples per plant). In the particular case of the bulk density and the in situ water content, three samples per depth were extracted with a core auger (six per plant).

\section{Rizosphere soil properties}

Each soil sample was sieved with a mesh opening size of $2 \mathrm{~mm}$ and air-dried. The analyses performed were texture by Bouyoucos hydrometer (Gee and Or, 2002), particle density $\left(D_{p}\right)$ with picnometers (Flint and Flint, 2002) and water retention curves with pressure plates (Dane and Hopmans, 2002). Bulk density $\left(\mathrm{D}_{\mathrm{b}}\right)$ was determined using cores (Grossman and Reinsch, 2002) and the in situ water content was obtained after oven-drying at $105^{\circ} \mathrm{C}$ for $48 \mathrm{~h}$ and converted to volumetric content using $\mathrm{D}_{\mathrm{b}}$.

The measured values of water retention were fitted to a $\mathrm{pF}$ curve using the software Ret-C (Retention Curve) (Van Genuchten et al., 1991). With the water retention curves fitted, the pore distribution was obtained using the calculated tension values and applying the capillarity equation described by Hillel (1998), which associates the tension values with a capillary radius equivalent to a soil pore radius.

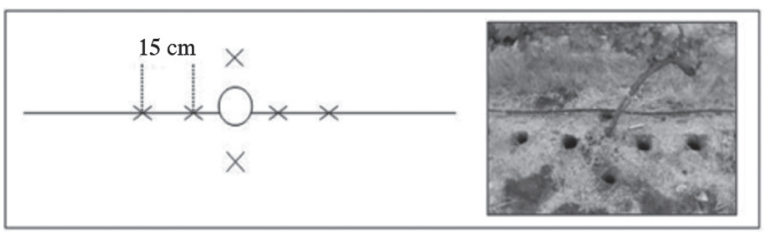

Figure 1. Scheme of extraction of the 12 soil samples on selected plants.

Table 1. Taxonomic and geographic details of studied soils.

\begin{tabular}{lcccc}
\hline Soil & USDA Classification & Geomorphology & Location & Slope \\
\hline S1 & Typic Xerochrept & Alluvial terrace & Casablanca & $2-5 \%$ \\
S2 & Entic Haploxerolls & Flood plane & Melipilla & $2-5 \%$ \\
S3 & Typic Xerochrept & Alluvial fan & Casablanca & $5-10 \%$ \\
\hline
\end{tabular}

S1: Soil 1; S2: Soil 2; S3: Soil 3. 
The pore size classification used in this study was the described by Pagliai and Vignozzi (2002), according with their function on soil. The pores between 0.005 and 0.5 $\mu \mathrm{m}$ are called "residual pores", between 0.5 and $50 \mu \mathrm{m}$ are "storage pores", between 50 and $500 \mu \mathrm{m}$ are "transport pores" and finally "fissures" over $500 \mu \mathrm{m}$.

Each sample of roots $\leq 2 \mathrm{~mm}$ was oven-dried at $70{ }^{\circ} \mathrm{C}$ and their dry-mass and length was determined on laboratory.

\section{Nematode assessments}

The nematodes were extracted from $250 \mathrm{~cm}^{3}$ of soil samples using soil sieving $(850,250,75$ and $38 \mu \mathrm{m})$ and a $48 \mathrm{~h}$ decanting period through a Baermann funnel (Christie and Perry, 1951). Counting was carried out with stereoscopic microscope (Zeizz, Stemi 200-C, with a KL 1500 cold light source) and identification was made based on Siddiqi (2000) identification key.

The statistic design was a randomized complete block design being each block a different soil. Into each block three rootstocks with five repetitions (five plants) were evaluated. Previously were checked the requirements of normality and homoscedasticity of the residues. Data were analyzed through an ANOVA and if significant differences were detected, the Student-Newman-Keuls test (SNK) was employed for means separation $(\alpha<$ $0.05)$. For nematode populations, a non-parametric ANOVA (Kruskal-Wallis test) was performed because its high variability.

To relate the multiple factors analyzed with nematode population, Stepwise regressions were used. To improve the accuracy of the Stepwise, the values for each variable were group according to rootstock, since it is the most influencing variable on plant parasitic nematode distribution (Aballay et al., 2009).

\section{RESULTS AND DISCUSSION}

\section{Pedon morphology}

The soil profile of S1 did not present structure (massive), it shows a sandy clay loam textural class on surface, overlaying an alluvial substratum composed by gravels and thicker fragments (granodiorite materials), with a compacted horizon at $40 \mathrm{~cm}$ although without drainage problems. Its effective depth was more than $100 \mathrm{~cm}$.

S2 profile had a better structured soil compared with the two others due to the greater amount of flocculants cations $\left(\mathrm{CaCO}_{3}\right)$ transported in water from the Maipo River, reflected on the measured $\mathrm{pH}$ and the strong reaction to $\mathrm{HCl}$ (data not presented). This profile shows a silty loam textural class on surface overlaying a cobbles substratum (10 cm diameter granodiorite materials) with sandy matrix and an effective depth of more than $90 \mathrm{~cm}$.

The S3 soil profile is very stratified and deep (> 100 $\mathrm{cm})$, predominating a sandy textural class. It has masstype redoximorphic features in depth over a compacted horizon at $113 \mathrm{~cm}$.

\section{Rizosphere conditions}

The studied soils present significant differences on their sand percentage. In general terms, S3 presents the higher sand percentage, followed by S1 and finally S2 with the lowest percentage (Figure 2).

The bulk density $\left(\mathrm{D}_{\mathrm{b}}\right)$ values for each soil were 1.45 , 1.21 and $1.42 \mathrm{Mg} \mathrm{m}^{-3}$ on surface and $1.51,1.16$ and 1.45 $\mathrm{Mg} \mathrm{m}^{-3}$ in depth for S1, S2 and S3, respectively (Table 2).

$D_{b}$ is a good indicator of soil densification, thus high values of it relates with less roots penetration and more air flux in soil, and in consequence a decrease on inhabitable-porous spaces. This effect has been reviewed

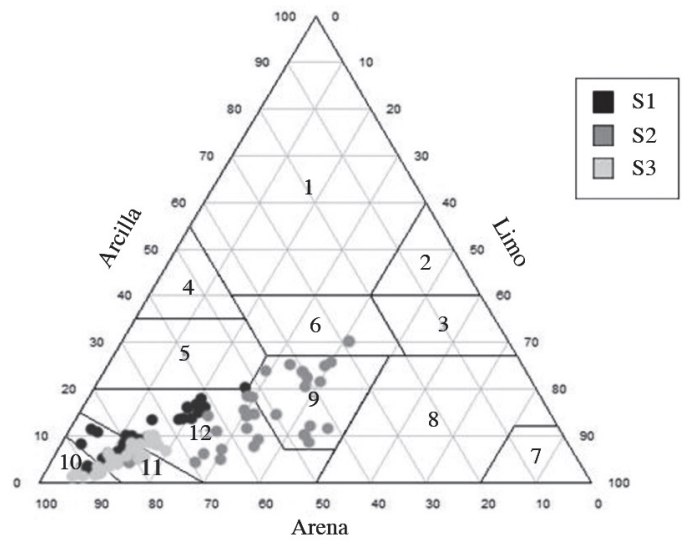

S1: Soil 1; S2: Soil 2; S3: Soil 3.
USDA Classification

\author{
1: Clay \\ 2: Silt clay \\ 3: Silt clay loam \\ 4: Sandy clay \\ 5: Sandy clay loam \\ 6: Clay loam \\ 7: Silt \\ 8: Silt loam \\ 9: Loam \\ 10: Sand \\ 11: Loamy sand \\ 12: Sandy loam
}

Figure 2. Texture values for all the samples. 
by several authors (Wallace, 1971; García del Pino, 1994; Neher et al., 1999; Yeates et al., 2002). In this study, S2 had a significant higher $\mathrm{D}_{\mathrm{b}}$ than the other soils and thus a significant higher total porosity too.

Porosity re-distribution on S1 was observed, although not significant, on the increase of the storage pores and consequent decrease of transport pores in depth because the densification observed on the morphological descriptions (Table 3).

$\mathrm{S} 2$ has a higher total porosity, with predominance in storage pores, indicating higher water retention available for roots and the creation of water transport-films too that allow nematode movement trough soil (Table 3 ).

S3 presents a proportion of transport pores higher than the other two studied soils, what matches with the predominant sandy texture class. The consequences of a higher large-pores proportion upon the edaphic microfauna has been reviewed by several authors (Wallace, 1971; García del Pino, 1994; Kay and Angers, 2000; Bouwman and Arts, 2001), since in these occur many of the biological soil processes.

The nematologic analysis detected genus and species (Table 4), but only Meloidogyne spp., Mesocriconema xenoplax, and Xiphinema genus were reviewed with detail, because its importance in terms of infectivity and damage on Chilean vineyards.

As expected the more susceptible rootstock to Meloidogyne spp. was 'Chardonnay' under the three different soil conditions, as observed by Cain et al. (1984) and Aballay et al. (2001), whom informed that 'Chardonnay' was highly sensible to this nematode.

The Meloidogyne genus is mainly associated to coarser textures (Wallace, 1971; Cadet et al., 2004; Jaraba et al., 2007); however in this study the highest population was on S2 (Table 4), which presented the lowest sand percentage.

It has been studied the effects of soil texture on the nematode population, but the results in most cases are contradictory. Esquivel (1996) pointed that capability of $M$. incognita $\mathrm{j} 2$ to migrate and penetrate roots it is inversely related with the silt plus clay percentage in soil; apparently the finer particles are obstacles for the nematode migration. Cadet et al. (2004) and Jaraba et al. (2007) revised that genus Meloidogyne presented higher frequency and abundance in sandy soils than clayey soils. Though, Avendaño et al. (2004) indicate that the

Table 2. Physical properties of the studied soils.

\begin{tabular}{|c|c|c|c|c|c|c|c|c|}
\hline Soil & Depth & $\mathbf{D}_{\mathbf{b}}$ & $\mathbf{D}_{\mathrm{p}}$ & Porosity & $\begin{array}{l}\text { in situ water } \\
\text { content }\end{array}$ & Sand & Silt & Clay \\
\hline & $\mathrm{cm}$ & $-\mathrm{Mg}$ & $m^{-3}$ & $\longrightarrow \mathrm{cm}$ & $\mathrm{cm}^{-3}$ & & $\%$ & \\
\hline \multirow[t]{2}{*}{$\mathrm{S} 1$} & $0-30$ & $1.45 \pm 0.06 \mathrm{c}$ & $2.74 \pm 0.02 \mathrm{a}$ & $0.47 \pm 0.02 b$ & $0.15 \pm 0.02 \mathrm{ab}$ & $74.98 \pm 2.36 \mathrm{c}$ & $14.15 \pm 1.53 \mathrm{a}$ & $10.87 \pm 3.13 b$ \\
\hline & $30-60$ & $1.51 \pm 0.06 \mathrm{~d}$ & $2.74 \pm 0.02 \mathrm{a}$ & $0.45 \pm 0.02 \mathrm{a}$ & $0.17 \pm 0.03 \mathrm{ab}$ & $75.51 \pm 4.61 c$ & $14.66 \pm 3.05 \mathrm{a}$ & $9.83 \pm 5.91 b$ \\
\hline \multirow[t]{2}{*}{$\mathrm{S} 2$} & $0-30$ & $1.21 \pm 0.07 \mathrm{~b}$ & $2.74 \pm 0.03 \mathrm{a}$ & $0.56 \pm 0.03 c$ & $0.14 \pm 0.01 \mathrm{ab}$ & $54.12 \pm 4.57 \mathrm{a}$ & $29.71 \pm 3.22 b$ & $16.17 \pm 3.59 \mathrm{c}$ \\
\hline & $30-60$ & $1.16 \pm 0.09 \mathrm{a}$ & $2.76 \pm 0.02 \mathrm{a}$ & $0.54 \pm 0.03 c$ & $0.18 \pm 0.03 a$ & $62.31 \pm 6.29 b$ & $30.98 \pm 5.25 b$ & $6.71 \pm 2.20 \mathrm{a}$ \\
\hline \multirow[t]{2}{*}{ S3 } & $0-30$ & $1.42 \pm 0.07 \mathrm{c}$ & $2.74 \pm 0.01 \mathrm{a}$ & $0.48 \pm 0.03 b$ & $0.13 \pm 0.01 \mathrm{ab}$ & $81.70 \pm 2.91 \mathrm{~cd}$ & $13.05 \pm 1.93 \mathrm{a}$ & $5.25 \pm 2.05 \mathrm{a}$ \\
\hline & $30-60$ & $1.45 \pm 0.09 \mathrm{c}$ & $2.75 \pm 0.01 \mathrm{a}$ & $0.48 \pm 0.03 b$ & $0.30 \pm 0.01 \mathrm{~b}$ & $84.45 \pm 3.57 \mathrm{~d}$ & $11.58 \pm 2.45 \mathrm{a}$ & $3.97 \pm 2.99 a$ \\
\hline
\end{tabular}

Mean values and standard deviation ( \pm ) for five repetitions. Statistical differences by columns with $\alpha<0.05$ test SNK (Student Newman-Keuls). $\mathrm{D}_{\mathrm{b}}$ : bulk density; $\mathrm{D}_{\mathrm{p}}$ : particle density.

Table 3. Approximate soil pores distribution by functional size.

\begin{tabular}{|c|c|c|c|c|c|}
\hline \multirow[b]{2}{*}{ Soil } & & Residuals & \multirow{2}{*}{$\begin{array}{c}\text { Storage } \\
>0.5 \text { to } 50 \mu \mathrm{m}\end{array}$} & \multirow{2}{*}{$\begin{array}{c}\text { Transport } \\
>\mathbf{5 0} \text { to } 500 \mu \mathrm{m}\end{array}$} & \multirow{2}{*}{$\begin{array}{c}\text { Fisures } \\
>500 \mu \mathrm{m}\end{array}$} \\
\hline & Depth & 0.005 to $0.5 \mu \mathrm{m}$ & & & \\
\hline & $\mathrm{cm}$ & & — Percentage $\mathrm{c}$ & soil volume & 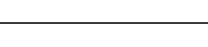 \\
\hline \multirow[t]{2}{*}{$\mathrm{S} 1$} & $0-30$ & $10.13 \pm 3.02 \mathrm{c}$ & $17.97 \pm 5.24 \mathrm{ab}$ & $11.77 \pm 4.06 b$ & $7.27 \pm 8.32 b$ \\
\hline & $30-60$ & $9.72 \pm 4.27 b c$ & $18.47 \pm 8.40 \mathrm{ab}$ & $9.65 \pm 5.30 b$ & $8.91 \pm 10.64 b$ \\
\hline \multirow[t]{2}{*}{$\mathrm{S} 2$} & $0-30$ & $11.37 \pm 2.63 \mathrm{c}$ & $32.68 \pm 3.38 c$ & $9.71 \pm 6.24 \mathrm{ab}$ & $1.37 \pm 0.99 \mathrm{a}$ \\
\hline & $30-60$ & $12.81 \pm 10.19 \mathrm{c}$ & $29.31 \pm 9.00 c$ & $8.75 \pm 7.13 a$ & $2.60 \pm 5.38 \mathrm{a}$ \\
\hline \multirow[t]{2}{*}{ S3 } & $0-30$ & $6.49 \pm 1.23 \mathrm{ab}$ & $21.19 \pm 7.61 b$ & $14.99 \pm 5.72 b$ & $5.33 \pm 4.34 b$ \\
\hline & $30-60$ & $5.16 \pm 2.06 a$ & $14.04 \pm 6.41 \mathrm{a}$ & $14.85 \pm 5.21 b$ & $14.39 \pm 10.32 b$ \\
\hline
\end{tabular}

Mean values and standard deviation ( \pm ) for five repetitions. Statistical differences by columns with $\alpha<0.05$ test SNK (Student-Newman-Keuls). S1: Soil 1; S2: Soil 2; S3: Soil 3. 


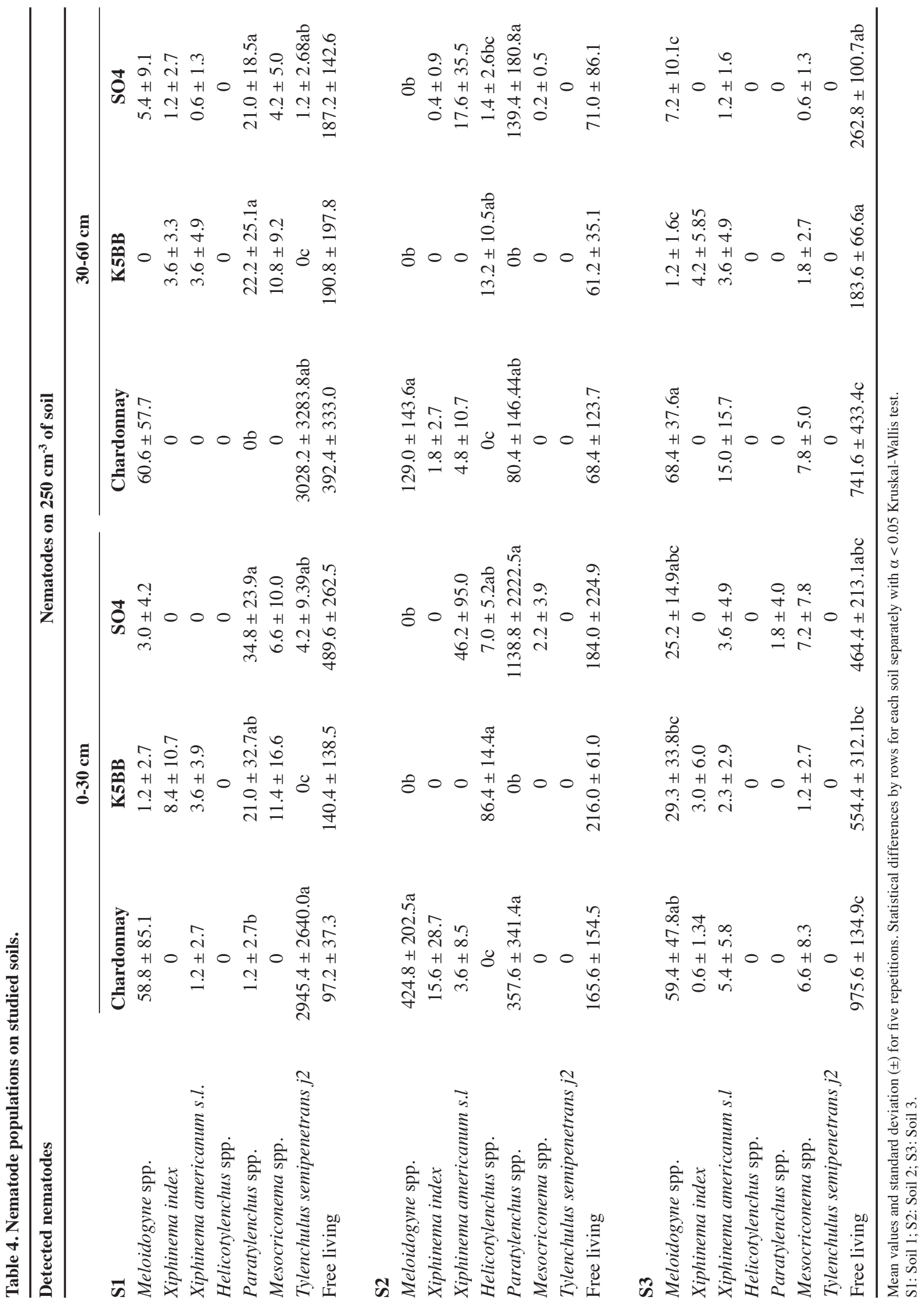


population density of the same nematode genus was associated with higher clay percentages. These differences on results show that other possible factors, like structure and air porosity (among others), are influencing the nematode populations on soil.

Mesocriconema xenoplax did not showed mayor correlation with the evaluated rootstock. In general terms, this species is known as a highly distributed nematode, however it is known that their damage increase when other nematodes are associated, generating a more susceptible stage in vineyards. Pinkerton et al. (1999) observed that $M$. xenoplax was associated to unhealthy plants giving examples of vineyards in Spain, Germany, France, Switzerland, and United States.

In the present study, it was observed a tendency of less nematodes of this gender on S2 (Table 4). Although, by the characteristics of this study and considering their low population it is not feasible establish relationships with the edaphic conditions.

The population of Xiphinema spp. was relatively low, considering that more than $100 \mathrm{X}$. americanum and $20 \mathrm{X}$. index are enough to be considered as a problem (González, 1993). No significant differences were detected ( $\mathrm{p} \leq 0.05)$, which supports that the rootstocks or soil characteristics had no effect on Xiphinema genus population. These results are coincident with the obtained by Aballay (2007), who observed an equally susceptible behavior in several rootstocks on different vineyards of Chile.

The same author explained that the combination of Xiphinema and Mesocriconema xenoplax may produce, in some cases, more damage than Meloidogyne spp. Since the populations of Xiphinema genus and Mesocriconema xenoplax were particularly variables, they eventually could transform into a potential problem on Chilean vineyards in the future (Table 4).

Despite their low agronomic importance (on vineyards) it has been observed that a large number of Tylenchulus semipenetrans j2 were detected on S1 where 'Chardonnay' presents higher populations than 'SO4' and ' $\mathrm{K} 5 \mathrm{BB}$ '. The symptoms of the attack of this nematode are expressed with less root development observed on Table 5. In the same way 'SO4' and 'Chardonnay' presents higher populations of Paratylenchus spp. on S2 but in this case 'SO4' did not presents evident root damage (Table 5).

\section{Stepwise regressions}

Nematode populations are affected by numerous factors that also have some interactions, for this reason relating a specific variable with nematode densities is a complex task.

To use stepwise multiple regressions, it was considered the influence of all the variables as a whole, over the studied nematode populations. Three models were chosen to present the interactions, under each studied nematode genus and species.

\section{Meloidogyne spp.}

Unlike observations made by many authors (Esquivel, 1996; Cadet et al., 2004; Jaraba et al., 2007), in this study the sand percentage was inversely proportional to Meloidogyne spp. j2 (Table 6), since the highest population was on S2 soil. Similar results were obtained by García del Pino (1994), on a study performed on Cataluña, where the main proportion of nematodes was in soils with loamy textural class. The explanation of these results may be related with the quantity of dried up pores, since the

Table 5. Total length of fine roots ( $<2 \mathrm{~mm}$ length) of rootstocks on three studied soils.

\begin{tabular}{|c|c|c|c|}
\hline \multirow[b]{3}{*}{ Rootstocks } & \multicolumn{3}{|c|}{ Soils } \\
\hline & S1 & $\mathbf{S 2}$ & S3 \\
\hline & \multicolumn{3}{|c|}{$0-30 \mathrm{~cm}$} \\
\hline & & \multicolumn{2}{|l|}{$\mathrm{cm}$ for $1500 \mathrm{~cm}^{-3}$} \\
\hline Chardonnay & $66 \pm 45.1 \mathrm{ab}$ & $117 \pm 15.3 b$ & $144 \pm 64.2 \mathrm{ab}$ \\
\hline K5BB & $103 \pm 20.8 \mathrm{ab}$ & $139 \pm 72.6 b$ & $217 \pm 33.8 \mathrm{a}$ \\
\hline \multirow[t]{2}{*}{$\mathrm{SO} 4$} & $80 \pm 33.7 \mathrm{ab}$ & $305 \pm 40.9 a$ & $249 \pm 66.6 a$ \\
\hline & \multicolumn{3}{|c|}{$30-60 \mathrm{~cm}$} \\
\hline & & $\mathrm{cm}$ for $1500 \mathrm{~cm}^{-3}$ & $\overline{ }$ \\
\hline Chardonnay & $56 \pm 29.8 b$ & $98 \pm 33.9 b$ & $97 \pm 19.0 b$ \\
\hline K5BB & $118 \pm 31.1 \mathrm{a}$ & $119 \pm 40.7 b$ & $100 \pm 16.1 b$ \\
\hline $\mathrm{SO} 4$ & $92 \pm 22.2 \mathrm{ab}$ & $305 \pm 40.9 a$ & $204 \pm 108.3 a$ \\
\hline
\end{tabular}

Mean values and standard deviation ( \pm ) for five repetitions. Statistical differences for each soil separately with $\alpha<0.05$ Kruskal-Wallis test. S1: Soil 1; S2: Soil 2; S3: Soil 3. 
loamy texture soils observed had better structure than the sandy ones, directly related with its higher organic matter content, reason why their air-porosity was superior. This results were observed in $\mathrm{S} 2$, that also had a better structure as it is described in the morphological descriptions (not presented), and a higher total porosity plus higher water retention pores as observed on the presented physical properties. Supporting this, 'SO4' presented the higher root development of the three studied soils (Table 5) highlighting the relation between soil conditions, root development, and nematode populations.

Finally the three regressions show that the fine roots development appears as a predominant factor and makes evident the roots-dependence of Meloidogyne spp.

\section{Mesocriconema xenoplax}

Mesocriconema xenoplax did not presented clear relationship with the observed factors. In the case of 'Chardonnay' and 'SO4' does not adjust any factor, and in the case of 'K5BB' it is more uncertain since the $D_{b}$ positively relates with the number of nematodes, which added to the low determination coefficient, it is not feasible relate soil properties with $M$.xenoplax population (Table 7).

\section{Xiphinema genus}

In this case and the same as $M$. xenoplax, there is a high variability in the results (Table 4). The presence of Xiphinema spp. in all the roots systems is explained by three different variables (Table 8), which added to the low determination coefficient value, it makes difficult establishing a clear relation with the soil properties.

\section{CONCLUSIONS}

The more influencing factor on the phytoparasitic nematode populations observed in this study was the use of rootstocks, however it has been observed that this effect was highly determined by the soil conditions, since the statistical differences between the rootstocks and the ungrafted variety were significant only in one soil. In this way, to consider the influence of the soil rhizosphere more than the root development by itself seems to be a more integral point of view on studies of nematode behavior.

An adequate morphological description of soil put on evidence determinant qualitative factors that helped to explain nematode activity like soil structure. In the same way, detailed analysis of the porosity distribution helped

Table 6. Stepwise regressions for Meloidogyne spp.

\begin{tabular}{llc}
\hline \multicolumn{2}{c}{ Stepwise regressions for Meloidogyne spp. } \\
\hline Chardonnay & $\mathrm{P}_{\text {mel }}=609.98-6.67 \mathrm{~s}-1.53 \mathrm{LRf}+184.15 \mathrm{MRf}$ & $\mathrm{R}^{2}=0.72$ \\
K5BB & $\mathrm{P}_{\mathrm{mel}}=5.36+0.39 \mathrm{LRg}-1.32 \mathrm{MRf}$ & $\mathrm{R}^{2}=0.47$ \\
SO4 & $\mathrm{P}_{\mathrm{mel}}=-2.66+0.39 \mathrm{LRg}-1.38 \mathrm{MRf}$ & $\mathrm{R}^{2}=0.59$ \\
\hline
\end{tabular}

$\mathrm{P}_{\mathrm{mel}}$ : population of Meloidogyne spp. s: sand (\%); MRf: mass of fine roots $<2 \mathrm{~mm}(\mathrm{~g})$; LRf: length of fine roots $<2 \mathrm{~mm}(\mathrm{~cm})$; LRg: length of roots $>$ $2 \mathrm{~mm}(\mathrm{~cm})$.

Table 7. Stepwise regressions for Mesocriconema xenoplax.

Stepwise regressions for Mesocriconema xenoplax.

\begin{tabular}{lll}
\hline Chardonnay & $\mathrm{P}_{\text {mes }}=$ Did not adjust to a defined model & $\mathrm{R}^{2}=---$ \\
K5BB & $\mathrm{P}_{\text {mes }}=-23.84+020.56 \mathrm{D}_{\mathrm{b}}$ & $\mathrm{R}^{2}=0.47$ \\
SO4 & $\mathrm{P}_{\mathrm{mes}}=$ Did not adjust to a defined model & $\mathrm{R}^{2}=---$ \\
\hline
\end{tabular}

$\mathrm{P}_{\mathrm{mes}}$ : population of Mesocriconema xenoplax; $\mathrm{D}_{\mathrm{b}}$ : bulk density $\left(\mathrm{Mg} \mathrm{m}^{-3}\right)$.

Table 8. Stepwise regressions for Xiphinema genus.

\begin{tabular}{lll}
\hline \multicolumn{3}{c}{ Stepwise regressions for Xiphinema genus. } \\
\hline Chardonnay & $\mathrm{P}_{\text {xiphi }}=-30.65-0.56 \mathrm{a}+143.940$ & $\mathrm{R}^{2}=0.34$ \\
K5BB & $\mathrm{P}_{\text {xiphi }}=-28.73-25.03 \mathrm{D}_{\mathrm{b}}$ & $\mathrm{R}^{2}=0.26$ \\
SO4 & $\mathrm{P}_{\mathrm{xiphi}}=-5.78+3.54 \mathrm{MRf}$ & $\mathrm{R}^{2}=0.19$ \\
\hline
\end{tabular}

$\mathrm{P}_{\text {xiphi: }}$ population of Xiphinema genus. $\mathrm{D}_{\mathrm{b}}$ : bulk density $\left(\mathrm{Mg} \mathrm{m}^{-3}\right)$; MRf: mass of the fine roots $(\mathrm{g})$; $\theta$ :volumetric water $\operatorname{content}\left(\mathrm{cm}^{3} \mathrm{~cm}^{-3}\right)$. 
to the better understanding of the processes involved on the nematode mobility and infectivity.

We proposed the use of Stepwise regressions, which resulted to be a useful tool when using multiple soil factors for explaining a single biological variable.

\section{RESUMEN}

Propiedades del suelo que influyen en la población de nematodos fitoparásitos en viñedos de Chile. El ciclo de vida de los nematodos fitoparásitos ocurre en la rizósfera, por lo tanto, sus dinámicas de alimentación, parasitismo y movilidad están inevitablemente influenciadas por la interacción suelo-raíz. Se llevó a cabo un estudio para evaluar la respuesta de diferentes portainjertos de Vitis frente a algunas poblaciones de nematodos fitoparásitos en diferentes tipos de suelos. Se determinaron las poblaciones de nematodos fitoparásitos en plantas de Vitis vinifera $\mathrm{L}$. var. Chardonnay sobre dos portainjertos (K5BB, SO4) y 'Chardonnay' sin injertar como testigo, en tres diferentes suelos aluviales de la zona central de Chile. Los suelos fueron dos Inceptisoles del Valle de Casablanca (Región de Valparaíso), uno sin estructura, con una zona de densificación en profundidad (S1), y otro de textura predominante arenosa (S3); un tercer suelo correspondió a un Mollisol mejor estructurado (S2), en la Comuna de Melipilla (Región Metropolitana). Los suelos fueron caracterizados física y morfológicamente y los géneros de nematodos fueron identificados y contabilizados bajo lupa estereoscópica. 'Chardonnay' tuvo las mayores poblaciones de Meloidogyne spp. aunque sólo significativas en el suelo S2. Las poblaciones de Xiphinema spp. y Mesocriconema xenoplax no fueron suficientemente representativas como para asociarlas a diferencias de suelo o uso de portainjerto. Meloidogyne spp. se relacionó inversamente con el contenido de arena, sin embargo, positivamente con la mayor estructuración del suelo. Las regresiones Stepwise fueron útiles al relacionar las poblaciones de nematodos con múltiples factores edáficos.

Palabras clave: Nematodos, portainjertos, K5BB, SO4, Chardonnay, suelo de la rizósfera.

\section{LITERATURE CITED}

Aballay, E. 2007. Evaluación y validación del comportamiento de portainjertos de vid a diferentes poblaciones de nematodos fitoparásitos en plantaciones comerciales de más de tres años. 144 p. Informe técnico final proyecto FIA-PI-C-20051-A-082. Fundación para la Innovación Agraria (FIA), Ministerio de Agricultura de Chile, Santiago, Chile.
Aballay, E.,P. Flores, y V. Insunza. 2001. Efecto nematicida de ocho especies vegetales en Xiphinema americanum sensu lato, en Vitis vinifera L. var. Cabernet Sauvignon en Chile. Nematrópica 31:95-102.

Aballay, E., y M. Montedónico. 2001. Evaluación de la resistencia de trece portainjertos de vid a Meloidogyne spp. en una viña de seis años. Aconex 72:18-28.

Aballay, E., P. Persson, and A. Mårtensson. 2009. Plant-parasitic nematodes in Chilean vineyards. Nematropica 39:85-98.

Arévalo, G.E., C.L. Zúñiga, V. Baligar, B. Bailey, y M. Canto. 2007. Dinámica poblacional de nematodos asociados al sistema de cultivo tradicional de cacao en la amazonia peruana. 8 p. In Taller PanAmazónico sobre Biodiversidad del Suelo, Rio Branco, Acre, Brasil. 26 y 29 de septiembre. Available at http://www.iamazonica.org.br/conteudo/eventos/ biodiversidadeSolo/pdf/resumos/Painel2_ArevalosE. pdf (accessed 9 October 2008).

Avendaño, F., F.J. Pierce, O. Schabenberger, and H. Melakeberhan. 2004. Spatial variability. The spatial distribution of soybean cyst nematode in relation to soil texture and soil map unit. Agronomy Journal 96:181-194.

Bell, N.I., R.N. Watson, and S.U. Sarathchandra. 2000. Suppression of plant parasitic nematodes in pastoral soils amended with chitin. New Zealand Plant Protection 53:44-47.

Bouwman, L.A., and W.B.M. Arts. 2001. Effects of soil compaction on the relationships between nematodes, grass production and soil physical properties. Applied Soil Ecology 14:213-222.

Cadet, P., S.D. Berry, and V.W. Spaull. 2004. Mapping of interactions between soil factors and nematodes. European Journal of Soil Biology 40:77-86.

Cain, C.W., M.V. McKenry, and R.E. Tarailo. 1984. A new pathotype of root-knot nematode on grape rootstocks. Journal of Nematology 16:207-208.

Christie, J., and V. Perry. 1951. Removing nematodes from soil. Proceedings of Helminthological Society of Washington 18:106-108.

CIREN. 1996. Estudio agrológico Región Metropolitana. Descripción de suelos, materiales y símbolos. Centro de Información de Recursos Naturales (CIREN). Publicación 115. 425 p. CIREN, Santiago, Chile.

CNR. 1981. Estudio agrológico del proyecto Maipo. 4 v. 802 p. Comisión Nacional de Riego (CNR), Agrolog Chile, Santiago, Chile.

Dabiré, K.R., and T. Mateille. 2004. Soil texture and irrigation influence the transport and the development of Pasteuria penetrans, a bacterial parasite of rootknot nematodes. Soil Biology \& Biochemistry 36:539-543. 
Dane, J.H., and J.W. Hopmans. 2002. The solution phase. Water retention and storage. p. 688-690. In Dane, J.H., and G.C. Topp (eds.) Methods of soil analysis. Part 4 physical methods. Book Series $N^{\circ} 5$. Soil Science Society of America, Madison, Wisconsin, USA.

Esquivel, A. 1996. Influencia del suelo sobre las poblaciones de nematodos p. 57-62. In Bertsch, F., W. Badilla, y E. Bornemisza (eds.) X Congreso Nacional Agronómico y de Recursos Naturales, EUNED, San José, Costa Rica. Available at http://www.mag.go.cr/ congreso_agronomico_X/a50-2388-III_057.pdf (accessed 17 May 2006).

Flint, A.L., and L.E. Flint. 2002. The solid phase, particle density. p. 229-240. In Dane, J.H., and G.C. Topp (eds.) Methods of soil analysis. Part 4 physical methods. Book Series $N^{\circ}$ 5. Soil Science Society of America, Madison, Wisconsin, USA.

García del Pino, F. 1994. Los nematodos entomopatógenos (Rhabditida: Steinernematidae y Heterorhabditidae) presentes en Cataluña y su utilización para el control biológico de insectos. 417 p. Tesis Doctor en Ciencias Biológicas. Universitat Autónoma de Barcelona, Facultad de Ciencias, Bellaterra, España.

Gee, G.W., and D. Or. 2002. The solid phase, particle size analysis. p. 255-293. In Dane, J.H., and G.C. Topp (eds.). Methods of soil analysis, Part 4 physical methods. Book Series № 5. Soil Science Society of America, Madison, Wisconsin, USA.

González, H. 1993. Nematodos vectores de enfermedades virosas. IPA La Platina (77): 18-21.

Grossman, R.B., and T.G. Reinsch. 2002. The solid phase, bulk density and linear extensibility. p. 201228. In Dane, J.H., and G.C. Topp (eds.) Methods of soil analysis. Part 4 physical methods. Book Series $\mathrm{N}^{\circ}$ 5. Soil Science Society of America, Madison, Wisconsin, USA.

Hillel, D. 1998. Environmental soil physics. 771 p. Academic Press, San Diego, California, USA.

Jaraba J., Z. Lozano, y M. Espinosa. 2007. Nematodos agalladores asociados al cultivo de papaya (Carica papaya $\mathrm{L}$.) en el departamento de Córdoba, Colombia. Agronomía Colombiana 25:124-130.

Kay, B.D., and D.A. Angers. 2000. Soil structure. p. A-229-276. In M.E. Sumner (ed.) Handbook of Soil Science. CRC Press, Boca Raton, Florida, USA.
Neher, D.A., T.R. Weicht, M. Savin, J.H. Görres, and J.A. Amador. 1999. Grazing in a porous environment. 2. Nematode community structure. Plant and Soil 212:85-99.

Pagliai, M., and N. Vignozzi. 2002. The soil pore system as an indicator of soil quality. p. 71-82. In Pagliai, M. and R. Jones (eds.) Sustainable land managementenvironmental protection, a soil physical approach. Advances in GeoEcology 35. Reiskyrchen, Germany.

Pinkerton, J.N., T.A. Forge, K.L. Ivors, and R.E. Ingham. 1999. Plant-parasitic nematodes associated with grapevines, Vitis vinifera, in Oregon vineyards. Supplement to the Journal of Nematology 31(4S):624634.

Prot, J.C., and S.D. Van Gundy. 1981. Effect of soil texture and the clay component on migration of Meloidogyne incognita second stage juveniles. Journal of Nematology 13:213-217.

Schoeneberger, P.J., D.A. Wysocki, E.C. Benham, and W.D. Broderson. 2002. Field book for describing and sampling soils. Version 2.0. 228 p. In Schoeneberger et al. (eds.) Natural Resources Conservation Service, National Soil Survey Center, Lincoln, Nebraska, USA.

Siddiqi, M.R. 2000. Tylenchida, parasites of plants and insects. $2^{\text {nd }}$ ed. 833 p. CABI Publishing, Wallingford, UK.

Smiley, R. 2005. Plant-parasitic nematodes affecting wheat yield in the Pacific Northwest. Oregon State University extension publication. EM 8887. 4 p. Available at http://extension.oregonstate.edu/catalog/ pdf/em/em8887.pdf (accessed 10 March 2006).

Van Genuchten, M., F.J. Leij, and S.R. Yates. 1991. The RETC code for quantifying the hydraulic functions of unsaturated soils. 117 p. EPA/600/2-91/065. U.S. Environmental Protection Agency (EPA), Ada, Oklahoma, USA.

Wallace, H.R. 1971. Abiotic influences in the soil environment p. 257-280. In Zuckerman, B.M., W.F. Mai, and R.A. Rohde (eds.) Plant parasitic nematodes. Vol. I. Academic Press, New York, USA.

Yeates, G.W., J.L. Dando, and T.G. Shepherd. 2002. Pressure plate studies determine how moisture affects access of bacterial-feeding nematodes to food in soil. European Journal of Soil Science 53:355-365. 